\title{
Zwycięstwa Jana Sobieskiego nad Turkami z perspektywy angielskiej
}

Elwira Buszewicz, Piotr Urbański 


\title{
Elwira Buszewicz, Piotr Urbański
}

\section{Zwycięstwa Jana Sobieskiego nad Turkami z perspektywy angielskiej}

ie tylko ludzie, ale równiez słowa przekraczają granice. Można też powiedzieć, że
pokonanie tej drogi niesie z sobą często istotne przemiany zarówno ludzi, jak i słów. Łukasz Górnicki umieścil w Durorzaninie polskim charakterystyczną refleksję:

\begin{abstract}
Abowiem nasz Polak, by jedno kęs z domu wyjechal, wnet nie chce inaczej mówić, jedno tym językiem, gdzie troszkę zmieszkał; jeśli był we Włoszech, to za każdym stowem Signor, jeśli w Francyej, to Par ma foie, jeśli w I Iiszpaniej, to Nos otros caraglieros; a czasem drugi, chocia nie będzie w Czechach, jedno iż granicę śląską przejedzie, to już inaczej nie będzie chciał mowić, jedno po czesku, a czeszczyzua, wie to Bóg, jaka będzie!.
\end{abstract}

Górnicki opuścil jednak z oryginału Baltazara Castiglionego równie charakterystyczną — wywodzącą się z Moralióu Plutarcha - narrację, którą przytoczymy tu za Tadeuszem Ulewiczem. Jest to opowieść

O kupcu z Lukki, skupującym w ,tamtych” stronach, tj. gdzieś na pograniczu z Moskwą, futra sobolowe. Kupcu, któremu się podczas wojny polsko-moskiewskiej trafiła ponoć $\mathrm{w}$ zimie fantastyczna przygoda $z$... zamarznięciem słów (!) wykrzykiwanych poprzez rzekę na odległość przez niezbyt dowicrzających sobie kontrahentów. Przygoda, w obliczu której Polacy musieli do-

' Cyt. za: Ł. Górnicki, Durorzanin polski, opr. R. Pollak. Wrochaw 1954 (BN I 109), s. 35-36. 
piero rozpalić ognisko, aby zamarzle już stowa odmurozić [sic!] i umoźliwić niefortunnemu rozmówcy ogólne przynajmniej ich zrozumienie ${ }^{2}$.

Górnicki z rozsądkiem trzeźwego empirysty odrzucił fantastyczne spekulacje południowców na temat stereotypu mroźnej północy. Kiedy jednak przyjrzymy się tej historii bliżej, możemy w niej odczytać pewnią uniwersalną metaforę. Przekraczając granice, słowa „zamarzają": kostnieją w formie odpisów czy druków, przekazywane zaś z ust do ust deformują się i zmieniają sens wypowiedzi. Ani państwowych, ani naturalnych granic nieraz do tego nic potrzeba; wystarczy drugi człowiek jako odbiorca, a potem nadawca tekstu. Przekonuje nas o tym dowodnie mechanizm plotki czy popularna zabawa w "ghuchy telefon”. Anegdota autora Du'orzanina uświadamia nam równiez inną prawidlowość: rzeczywistość spoza granic widzimy często w sposób z góry uksztaltowany, przez pryzmat uprzedzeń i przesądów.

Przystępując do badania nieznanego dotąd u nas tekstu nowołacińskiego ${ }^{3}$, pragniemy odpowiedzieć między innymi na pytanie, jakie czynniki uksztaltowały obraz Sobieskiego i Sarmacji przedstawiony w ulotnym druku panegirycznym angielskiego autora: Pio, inticto, felici principi Iohanii Poloniae Regi, Magno Duci Lithuanie, etc., carmen paneryricum; quo stupendae illae victoriae a Turci reportatae ordine recitantur.

Niewiele pomoże nam w tym sylwetka samego twórcy, o którym wiadomo tylko tyle, że nazywał się William Smith, był Anglikiem i wydał swe dziełko w oficynie Johannesa Gellibranda w Londynie w roku 1679. Nazwisko Smith nie wydaje się czymś na tyle rzadkim w tradycji brytyjskiej, by mogło ulatwić identyfikację osoby je noszącej. Zanim więc tożsamość naszego tajemniczego bohatera zostanie ostatecznie ustalona ${ }^{4}$, spoglądać nań będziemy przezz pryzmat jego dzieła.

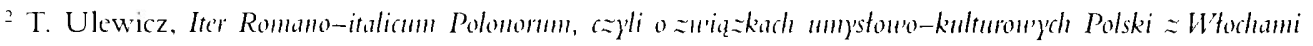
"' u'ickuth średnich i Rénésansie, Kraków 1999, s. 180.

${ }^{5}$ Druku tego nie wymienia ani B. Klimaszewski.Jan III Sobieski u' literaturze polskicj i zachodnioenropejskiej

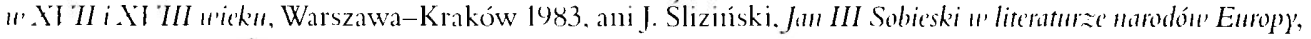
Warszawa 1979. U Ślizińskicgo rozdział omawiający litcraturę angiclską i ancrykańską (s. 372 i nast.) jest dość skromny. u Klimaszcwskicgo zaś. gdzic Anglia omówiona została na stronach 186-189. nie ma żadnego druku z 1679 roku, ponadto wymicnionc zostały wylącznic pisma w j̧̨zku angielskim. Korzystamy z egzcmplarza Bodleian Library w Oksfordzic. sygn. Wood 113 (7). Być może jest to jedyny zachowany egzemplarz tckstu w Wiclkicj Brytanii.

+ W czasach. w których powstal interesujący nas panegiryk, źródla biograficzne (up. oksfordzki Dictionary' of . Vational Biographly') notuja miçdzy innymi Williama Smitlia, aktora, zmarkego w 1695 roku. Williama Smitha. pisarza i czlonka wspólnoty kwakrów, zmarłego w roku 1708, czy innego jeszcze Williama Smitha, aptckarza z Shrewsbury (ok. 1750-1736). Pozornic prawdopodobny wydaje siç William Smith (ok. 1651-1735), który wpisal siç na uniwersytet oksfordzki w 1668 roku; tam też uzyskal bakalaureat (1672) i magisterium (1675); sprawował władzç w kolegium, a potcm (od 1704) zarządzał parafią w Melsonby. Znany on jest jeduak glównic jako badacz archiwalnycl dokumentów i autor prac o charakterze antykwarycznym. Źródla bibliograficzne (Wing oraz English Short-Title Cataloguc') wymieniają tymczasem sicdemnastowiecznego poetę Williama Smitha (bez żadnych jednak uściśleń biograficznych), autora między 
Wiersz ma typową postać panegiryku przystającego do definicji, którą za dawnymi podręcznikami wymowy przytoczył ostatnio Jakub Niedźwiedź: powinna to być „forma mowy pochwalnej, którą wygłoszono publicznie wobec jakiegoś znaczącego audytorium" Badacz dodaje, że twórczość pochwalna, ukierunkowana przede wszystkim na powszechność odbioru, utrwalana była clıętıie w postaci druku, który zapewniał maksymalnie szerokie audytorium.

W panegiryku chodziło przecież o dotarcie do jak największego grona słıchaczy, czytelników lub widzów, i zaświadczenie o czyjejś cnocie. (...) Druk przejąl wspomnianą wyżej funkcję docierania do jak największej liczby osób. Mowa nie była już wprawdzie ..mówiona w licznym zacnych gości gronie wspaniale i poważnie”, ale jej odbiorcami byli „zacni czytelnicy”.

Karta tytułowa utworu Williama Smitha świadczy o świadomości wspomnianej funkcji panegiryku. Czytamy bowiem:

Pio, Invicto, Felici Principi Iohanni Polonine Regi, Magno Duci Lithuaniae etc. Carmen Panegyricum; quo stupende illae victoriae a Turcis reportatae recitantur

Pieśí panegiryczna ku czci Pobożnego, Niezwyciężonego, Szczęsnego władcy, Jana, Króla Polskiego, Wielkiego Księcia Litewskiego etc., w której głosi się należycie owe zadziwiające zwycięstwa odniesione nad Turkami?

Cel autora - dotarcie do szerokiego audytorium i zaświadczenie wobec niego o cnocie Sobieskiego - zaznacza się tı wyraźnie. Nie chodzi tı, co oczywiste, o wiktoriç wiedeńską, gdyż na nią musielibyśmy czekać jeszcze cztery lata od momentu ukazania się dziełka. Zwycięstwa zostały tu wymienione w liczbie mnogiej, i jak wynika z treści utworu, trzeba tu mieć na uwadze głównie kampanię chocimską z 1673 roku oraz obronę Lwowa z roku 1675. Nie chodzi jednak wyłącznie o upamiętnienie zwycięstw: istotna jest przede wszystkim lau-

innymi następujących utworów: Carmen triumphale... 1660; De urbis Londini incendio clegria, 1667; Of the celebration of the king's commation day.... Bathe, 1661: A poem on the... ship, aalled the Ley al Londen, 1666; Pocma in honorem dignissimi Guilhelmi Timmer, equitis unmati, Londini praetoris, 1669, oraz naszego pancegiryku.. Jeśli poeta ten jest autorem wszystkich wymicnionych tu pocmatów, nic możeny utożsaniać go ze wspomnianym .,antykwariuszem”. gdyz ten nic bylby chyba zdolny napisać Carmen triumphlale w wicku lat dziewięciu. Za pomoc w poszukiwaniach dziçkujemy 1)r. Davidowi Moncy z Cambridge University.

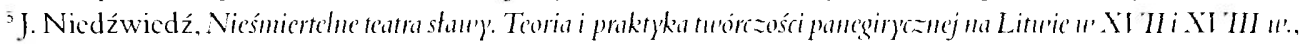
Kraków 2003, s. 89.

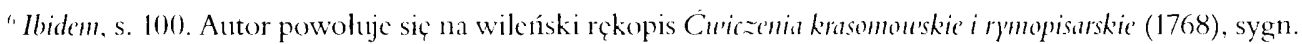
BUV F3-454, s. 168.

${ }^{7}$ Tu i ponizej fragmenty pocmatu w przckladzic polskim autorstwa Elwiry Buszewicz. 
dacja konkretnej osoby, jej etosu, przeświecającego przez garść danych biograficznych, historycznych i politycznych. Charakterystyczne wydaje się motto, przejęte z Klaudiana:

Ultro se purpura supplex

Obtulit, et solus mernit regnare rogatus

Purpura sama pokornie prosiła, by ją przyjąl, on też jeden zasłużył na to, by królować, kiedy go poproszono.

Motto to blyskotliwe i trafnie dobrane, trafiniej chyba nawet niz slynny cytat z Ewangelii, zastosowany w odniesieniu do Sobieskiego przez jednego z kaznodziejów: „Pojawił się człowiek zesłany przez Boga, Jan nu było na imię" ". W przypadku motta z Klaudiana znaczenie posiada bowiem nie tylko tekst, ale i jego kontekst. Cytowany fragment pochodzi bowiem z wiersza De quarto consulato Honorii Augusti i odnosi się do pochwał ojca adresata, Teodozjusza I. On właśnie przedstawiony został jako zdecydowany poskromiciel „Getów” i „Bistonów” (jak wiadomo, pod tymi imionami literatura nowołacińska częstokroć przedstawiała Turków, analogia narzucala się zatem sama).

Dziełko Smitha ma zdecydowanie charakter sylwiczny. Mieści w sobie elementy typowego panegiryku biograficznego, epiki heroicznej, twórczości epitalamijnej, poematu okolicznościowego. Podążmy za treścią utworu, pełnego dygresji i ozdobników. Najpierw pokrótce: introdukcja ma charakter nieco iluzjonistyczny, ponieważ, będąc obrazem zwycięskiego triumfu, zapowiada cammen gratulatorium. Po pompatycznej zapowiedzi autor odkrywa swoje intencje: będzie to jednak wiersz portretujący bohatera w szerszym kontekście. Najpierw więc (s. 6-7) mowa o młodości bohatera, dalej (s. 8-16) - o jego małżeństwie. Potem krótka refleksja o abdykacji Jana Kazimierza i elekcji Michała. Kolejne trzy strony poświęcone są przeglądowi sytuacji politycznej, mianowicie sprawie Doroszenki, zdobyciu Krety kończącemu wojnę Porty z Wenecją oraz inwazji Tatarów na Podole. Od strony 20 zaczyna się portretowanie Sobieskiego jako męża opatrznościowego, wyznaczonego przez sily nadprzyrodzone do rozprawy z wrogiem. Pod konice strony 21 zaczyna się opis kampanii chocimskiej, poczynajac od wkroczenia Sobieskiego na wat tureckiej twierdzy. Opowieść ta, wzbogacona dodatkowymi refleksjami, kończy się w pierwszych wersach strony 25, po czym autor przechodzi do omówienia elekcji Sobieskiego i jego koronacji. Pozostajemy tu aż do strony 33 w świecie mitu i poezji, ponieważ twórca najprawdopodobniej łączy własne refleksje z wiedzą o jakimś okolicznościowym przedstawieniu towarzyszącym uroczystościom". Następnie wkraczany znowu w świat potyczek Marsowych, gdyż autor

"Por. Z. Wójcik. Jan Sobieski 1629-1696. Warszawa 1983, s. 220. Kaznodzicja użył cytatu (J 1,6) w lacińskiej wersji Wulgaty: Fuit homo missus a Deo, ani momen crat Iolummes.

${ }^{4}$ Nalezaloby porównać narrację Smitha z zawartością druku .4 trice relation of the manner of the Coronation of the present King of Poland, jaki ukazal się w Londynie w 1676 r. 
relacjonuje kampanię lwowską z 1675 roku. Na stronie 37 nakreślony zostal obraz powracającego pokoju i tryumfu mężnego króla, strona kolejna otwiera natomiast finaluą, rozciągającą się aż do strony 40, prozopopeję Europy, zachęcającej Sobieskiego i wladców innych państw do walki o odzyskanic władzy nad Wschodem.

Autor, jak każdy poeta nowołaciński, jest imitatorem, i to zręcznym imitatorem. Nie pisze centonu, ale w niektórych partiach zdarza mu siç bardzo mechaniczne naśladowanie znanych sobie utworów, zarówno co do układu wydarzeń, jak i warstwy stowno-retorycznej. Trudno czasem dokladnie ustalić, kiedy podąża za autorami antycznymi, a kiedy za ich nowołacińskimi naśladowcami. Najsilniej jest to widoczne w części epitalamijnej utworu, w której widać wyraźne zbieżności z utworem holenderskiego poety Kaspra Barlaeusa $I c$ mus Batan'a". Tu Cyterejka zwraca się do oblubieńca:

Te propter Paphias arces Cyprumique reliqui,

Idalimmone nemus. geniales promuba tedas

Ipsa puerque mens forimus quid lenta moraris

Vota? (w. 160-164)

Smith natomiast każe tak przemówić Wenerze do Sobieskiego:

Te propter Cyprumque Paphonque reliqui

Diva libens. Ferimus geniales promuba taedas

Ipsa, Puerque mens. Quid gaudia, lente, moraris? (s. 14)

Z twego powodu Pafos cypryjskie zechcialam

Ja, bogini, opuścić. Ślubne niesiemy pochodnie,

Ja, i syn mój. Dlaczego mialbyśs radość odwlekać?

Oba teksty wykazują zależność retoryczną od Klaudiana", ale bardziej ścisłe podobieństwo widać między tekstami Barlacusa i Smitha. Uderzającą zbieżność obu utworów widać w opisie dnia zaślubin. U angielskiego poety:

Progreditur lux grata polo; nee mubila coclum,

Nec terras caligo tegit; disperserat omme's

Nam Pater aetherens temebras, quo darior orbem

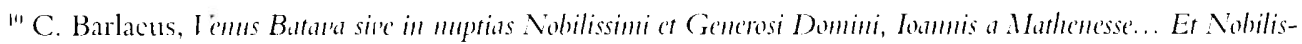
simae Lirginis ar Dominac, Wilhelminae Indith Pieck. w: idem, Poemata. t. 1, Amsterdam 16+5. s. 359 i nast. (Poematum heroicormu liber III. narii argumenti).

"Por. w Epitalamimm dla Marii i Honorinsza, ww. 256-260): salme siderenc proles angusta Serchae, / magnorum suboles regum parituraque reges: / te propter Paphias sedis Cypromique reliqui, / te propter libuit tantos explere labores.
} 
Iirgineus collustret apex, Solisque lacessat

Lumina (s. 16).

Miłe się słońce w tryumfie toczy; nieba nie kryją

Chmury ni ziemi ciemności, bowiem Ojciec niebieski

Wszelkie mroki rozproszył, aby korona dziewicy

Jaśniej światu świecila, idąc ze słońcem w zawody.

U Barlaeusa tymczasem:

Ennicuit lux alma polo. disperserat onmes

Ipsa pater Dibum mebulas, quo clarius orbem

I'irgincus collustret apex, Solemque lacessat

I iultus (w. 229-232).

Podobieństw tych jest dużo więcej, choć brak tu miejsca na dokładniejsze ich roztrząsanie. Wydaje się w każdym razie, że wiersz Barlaeusa służył Smithowi za „matrycę” części epitalamijnej panegiryku, z której nie wahał się czerpać pełnymi garściami.

Smith podąża często również za antycznymi autorami. Kiedy w związku z uroczystościami koronacyjnymi przedstawia cykl obrazów mitologicznych, podejmuje między innymi wątek Jazona i Argonautów. Idzie wtedy wyraźnie za poematem Valeriusa Flaccusa Argonantica. W innych partiach widać u niego silny wpływ panegiryków i utworów okolicznościowych Klaudiana, sylw i Tébaid) Stacjusza, a także poematu Siliusa Italicusa Punica. I Jistoria wojen Rzymu z Kartaginą stanowi nieraz w naszym panegiryku punkt odniesień porównawczych. Kanon bliskich sobie poetów starożytnych przedstawia zresztą sam antor, mówiąc o elekcji i koronacji hetmana:

Hic Latialis Homerus

It medins; casto divina modestia vultu

Lucet, et intactis cinguntur tempora vittis;

Huic l'arus, Gallusque, huic doctus Horatius haeret,

Et lactus Scythicos, tu, Naso, revisere campos

Festinas, charo gressus comitante Tibullo;

Statius, et Silii lauro frondente secures

Ielatae, Ausoniique gravis, sanctique Boethi

Procedunt Fasces. Illi decorare trimmphos

Sauromatum properant, expectatumque sacrato

Carmine concelebrare diem (s. 26).

Pośrodku kroczy Homer laciniski;

Lśni przeczyste oblicze boską zaiste skromnością, 


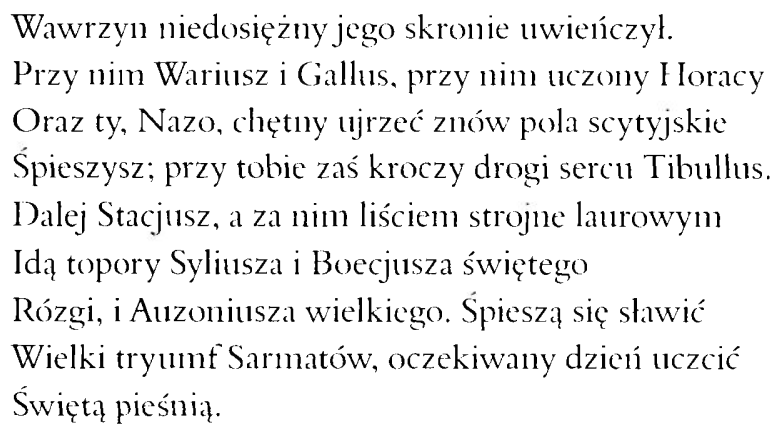

Najbardziej ukochanym poetą angielskiego panegirysty wydaje się jednak Owidiusz, którego losowi poświęca Smith liryczną dygresję i którego tlegie, zwłaszcza wygnańcze, cytuje z upodobaniem. Nie tyle jednak chcemy tu badać gust literacki autora i jego talent poetycki, lecz raczej pragniemy poświęcić nieco uwagi zagadnicniom bardziej związanymi z kontaktami kulturowymi między państwami. Kim jest dla autora panegiryku Sobieski? Co ów autor wie o nim oraz o Polsce, a czego zdecydowanie nie wie? Czy w lacińskim tekście ujawnia się brytyjskość, ba, angielskość poety? Jaka jest jego kultura polityczna? Jaka wizja państwa i wladzy?

Jak wiadomo, w czasach nowożytnych posługiwano się topiką pochwalną opracowaną przez autorów rzymskich, glównie Kwintyliana i Pryscjana z Cezarei. Loci pochwały człowieka zostały podzielone przez nich na dwie grupy: pierwsza skupiała się wokół laudacji ante vitam, in vita oraz post t'itam; druga wykorzystywała toposy pochwaly, ukazujące bohatera jako glówna postać otaczającej go rzeczywistości ${ }^{12}$. Ze zrozumialych względów autor naszego panegiryku wybiera ten drugi model. Ma zatem do wyboru dobra ciala, unyshı i Fortuny. Z największym upodobaniem przedstawia te ostatnie, zwlaszcza szeroko pojętą virtus. Przejawia się ona już w okresie młodzieńczym. Omawiając pierwsze wypady wojenne przyszłego króla u boku ojca, Jakuba, poeta posługuje się porównaniem homeryckim:

Sic Leo, quun terris Nox primam indwxerit umbram,

Prorumpit tacitis Nato comitante latebris,

Cogit quippe fames; sedes prior ipse ferarmm

Vestigat Senior; coeptis gencrosa paternis

Erigitur Proles; praedaque ferocior instat (s. 6-7).

Tak czyni Lew, kicdy noc już ziemię cieniem okryje,

Rusza z ostępów na lów z mlodym szczenięciem u boku,

Gdy ponagla ich głód; wpierw ojciec tropi kryjówki

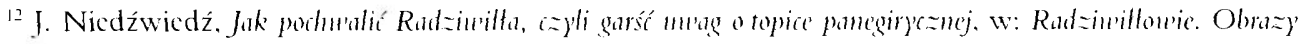
literackic, biografic, suriadectura histor)ene. red. K. Stçpnik. Lublin 2003.3. s. 193. 
Zwierząt, a dzielny syn, za jego idąc przykładem,

Coraz odważniej próbuje na swoją zdobycz napadać.

Zauważmy, że podobnym konceptem pochwalnym posłużył się Jan Kochanowski w Jeździe do Mosku'y, mówiąc o Krzysztofie „Piorunie”:

Jako więc orzeł mlody, na gnieździe wysokiem

Siedząc, za ojcem patrza niespuszczonym okiem,

Kiedy albo wysoko buja pod obloki,

Albo prędki zwierz goni i drapieżne smoki (...)

Tak ty, przypatrując się ojcowskiej dzielności,

O zacny Radziwille, z napirwszej młodości

Myśliłeś zawżdy slawy domowej poprawić (... $)^{13}$

Kochanowski traktuje ten passus jako koncept heraldyczny ${ }^{1+}$. Smith stosuje w podobnej funkcji figurę lwa. Nie wiemy, czy transponuje w ten sposób na naszą rzeczywistość brytyjski koncept herbowy, czy może znana jest mu metafora „Lwa Lechistanu”, jakiej powszechnie używano względem Sobieskiego w literaturze ${ }^{15}$. Notabene nigdzie nie rozwija Smith stricte heraldycznego toposu Janiny, jakże popularnego w literaturze okolicznościowej poświęconcj walecznemu królowi ${ }^{16}$, a o tarczy jako takiej wspomina w całym poemacie raz tylko, opisıjąc postać Odyna.

Obok młodzieńczej ı'irtus bojowej szeroko slawi Smith równicż wyksztalcenie bolnatera, akcentując jego pobyt we Francji i wnikliwie charakteryzując znajomość starożytnych poetów, historyków i filozofów. Jak wiemy, o wyksztalcenie Sobieskiego zatroszczono się należycie ${ }^{17}$, toteż panegirysta nie musial tu ani za dużo upiększać, ani znaleźć się w tak kłopotliwej sytuacji, jak imć pan Pasek, który, wygłaszając mowę pogrzebową ku czci zmarlych weteranów, musiał posłużył się słowami:

${ }^{13}$ J. Kochanowski. Jezdu do .Mos''1'y', w: Dzicta polskie, opr. J. Krzyżanowski, Warszawa 1989, w. 1-4 i 11-14. ${ }^{1+}$ J. Nicdźwicdź. Jak pochuralie Radzinitha.... op. cit., s. 196.

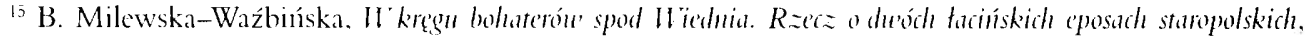
Warszawa 1998, s. 93-94.

" Por. D. Chemperek, wst. do: J. Gawiński, Clipaens Christimitatis to jest Tare Chrześijaństu'a, opr. D. Chemperek, W. Walccki. Kraków 2003 (Biblioteka Tradycji Litcrackich +7), s. 8-10. Tu (oprócz dzicla Gawińskicgo) wymieniono utwory nawiązujące do tego konceptu, miçdzy innymi prace młodzicży akademickicj. Stanislawa Bicżanowskicgo, J. Janscniusa, I. Straucha, J. Kwiatkiewicza. S. Szemiota, R. Arteńskicgo etc.

1- Por. na ten temat II. Barycz, Latua szkolnc. Marka i Jann Sobieskich, Kraków 1939. 
Którzy w młodości zaraz swojej, ledwie tak rzec nie mogę, że prawic a cunabulis, bo w chłopięcych latach, nie wdając się w pieszczonej Pallady instytucyją, udali się ochotnie do przykrej, krwawej Bellony palestry ${ }^{18}$.

Nasz panegirysta może z całą powagą powiedzieć:
Sed nec sola tibi tristis Bellona voluptas
Aut fremitus spumantis equi; Felicilus ausis
Doctrinae succrescit amor. Tibi Gallia fusas
Pandit opes, Latiaeque togae monumenta letustas
Explicat, ac primos aperit grandac'ra Pelasgos (s. 7).
Lecz ty rozkosz miałés nie tylko u smutnej Bellony,
Albo z rżenia spienionych koni. Szczęsne wyczyny
Idą w parze z miłością wiedzy. Galia dla ciebie
Swe bogactwa rozlewa, a starożytność tlumaczy
Rzymskiego prawa ustawy i wiedzę Greków pradawnych.

Bardzo osobliwie przedstawia się w naszym panegirykı kwestia królewskiego małżeństwa. Powoluje mianowicie autor do istnienia na pól fantastyczną królową Polski. Jest to, owszem, Marysieńka, ale... Maria Ludwika Radziwiłlówna, „siostra księcia Radziwiłła”. Być może autor wiedział o koligacjach Sobieskich z Radziwiłlami, nie wiedział natomiast ani o francuskim pochodzeniu m-lle d'Arquien, ani o jej małżeństwie z Janem Zanoyskim-Sobiepanem, a tym bardziej o sekretnych ślubach ${ }^{19}$, na wieki upamiętnionych z dużą dozą sarkazmu przez Jana Andrzeja Morsztyna. Odbiorcę znającego dzieje małżeństwa Sobieskiego jakże musi zdumiewać sielankowy obrazek epitalamijny, w którym geniusz Sarmacji przybywa na łąki Wenery i prosi o skojarzenie stadła Sobieskiego z czystą i wstydliwą Marią Radziwilłówną. Wenus przybywa najpierw do Wilna, gdzie, jak przypuszcza autor, rezyduja Radziwiłłowie, a potem do Krakowa, gdzie z jakiegoś powodu powinna się mieścić rezydencja Sobieskich. Ani o Olesku, ani o Żólkwi nic autorowi nie wiadomo. Nie sposób powstrzymać uśmiechu, gdy czytamy wypowiedź Wenery skierowaną do młodej Marii:

\author{
O magno socianda Duci, parituraque Reges \\ Nympla noves! Tencros cur tingit purpura vinltus \\ Per niveas suffusa genas? Nimis anvia res est \\ Virginitas; socii nescis concordin lecti
}

\footnotetext{
IH J. Pasck, Pamiętniki, opr. R. Pollak. Warszawa 1989, s. 51.

"Por. Z. Wójcik. op. cit.. s. 100 i nast.: por. tez T. Żcleński-Boy, Marysieńka Sobieska, w: idem, Pisma, red. H. Markiewicz, t. 7. Warszawa 1956. passim.
} 
Gaudia. Iam risus nostros, ac mumia matris

Scire invet (s. 13).

Ty, co z wielkim się zlączysz Wodzem, rodzić nowych

Będziesz, o nimfo, królów! Czemu lica Twe śnieżne

Tak oblala purpura? Dziewictwo to zbyt uciążliwa

Rzecz $^{20}$. Ty nie znasz jeszcze uciech malżeńskiej lożnicy.

Poznaj już nasze radości, i poznaj także matczyne

Powinności.

Nie da się jednak ukryć, że jakkolwiek autor panegiryku rozmija się nieraz z rzeczywistością historyczną, to stan zakochanego Sobieskiego oddany został ze szczególną prawdziwością?

\section{(...) Tu, Princeps aperis penetrabile telis}

Pectus, et effusac laxas praecordia flammate

Et sordent iam pacis opus, bellique tumultus;

Nec venator equus tibi cura, nec antra ferartum,

Latratorte canis; Soli largiris amori

Omuia; suspensosque putas procedere soles

Noctumasque hacrete rotas, dum promubus $H_{y}$ men

Tardior Augustae differt soleminia taedae (s. 15).

(...) Ty, książę, pierś pozwalasz strzalami

Przeszyć i serce otwierasz na żar rozlany szeroko.

Gardzisz już dziełem pokoju oraz wrzawą wojenną,

Nie dbasz o konia na łowy, ani o zwierząt kryjówki,

Ani o charta szczekanie. Samej miłości poświęcasz

Wszystko. Każdy wschód słońca blady ci się wydaje,

Noc zatrzymana na dłużej, póki I lymen weselny

Wciąż odkłada na później swych ceremonię pochodni.

Cojakiś czas autor pozwala sobie na dygresję i refleksję polityczną. Tu ujawnia się w pełni jego brytyjskość oraz ogólne wykształcenie humanistyczne. Gdy mówi o abdykacji Jana

\footnotetext{
"W oryginale , mimis amxia res est lirginitas". dostownic jak u Barlacusa. op. cit., w. 98-99.

${ }^{2}$ Por. np. opiniç Z. Wójcika, op. cit., s. 101: ..Sobicski oszalat - tak bez zbytniej przesady możua określić jego stan. Chęć jak najszybszego związania się̧ węzłem malżeńskim z ukochaną od lat kobictą owładnęla nim bez reszty".
} 
Kazimierza, w pierwszej kolejności przywołuje analoggię z angielskim królem Iną, a potem dopiero abdykację Karola Vw 1556 roku oraz cesarza Dioklecjana.

Na postać Michała Korybuta Wiśniowieckiego patrzy panegirysta Sobieskiego z perspektywy zwolenników tego ostatniego. Nie nazywa wprawdzie króla, jak oni, ..malowanym ryłem" "2? ale wskazıje nikłe zdolności polityczne tego wladcy, skontrastowanego wyraźnie z Sobieskin. Oto przed bitwą chocimską:

Magnatum riguere manus; et mentis, et omnis

Consilii melioris inops Rex ipse periclis

Cedit, et infelix accensas aspicit Urbes.

Tu, Ductor, tantis obstas horrentibus armis

Intrepidus, mediaque affers sub morte Polonis

Praesidium, roburque tuis (s. 21).

Ręce magnatów zdrętwiały, a król umysłu wąttego,

Rady lepszej pozbawion, wśród grozy na duchu upada.

I nieszczęsny spogląda na miasta wokól płonące.

Ty zaś, wodzu, bez lęku odpór dajesz straszliwej

Broni, wśród żniwa śmierci niesiesz swoim Polakom

Moc i pewną obronę.

A potem

Rex Michael, aegres reforens sub mente dolores ${ }^{23}$,

Succumbit fatis (s. 25).

Juz król Michal, któremu choroba do głowy uderza,

Życic oddaje.

Ta wizja rzeczywistości politycznej zgodna jest z ocena późniejszych historyków. Nieco inaczej widziały to masy szlacheckie, których Wiśniowiecki był wybrańcem. Takie spojrzenie, idealizujące nieco postać monarchy, który podobno, jak orzekł Wacław Konopczyński, „znał osiem języków, ale w żadnym z nich nie miał nic ciekawego do powiedzenia”"t, widzimy w poemacie epickim Daniela Kataja Klimakteryk heroicznl:

${ }_{22}$ Por. ibidem, s. 189. Innym epitetem z paszkwilów by tytul: „Michut Skrohibut Poloniace, Andreae Olszon'ski gratia Rex".

23. Tu przyp. Smitha ośmicrei Korybuta Wiśniowicckiego: ... Vidhat Poloniac Rex moritur, Nolémb. 11). 1673".

${ }^{2+}$ Cyt. za: Z. Wójcik, op. cit.. s. 16,3. 
To gadka - Michal z swymi aniolami

Idzie na smoka, żeby go zwojował.

Idzie król polski ze dwiema wojskami

Pod Lwów na Turka. Tamże zachorowat.

Tu MARS, a tu MORS - przyznacie sami,

I I Ierkules by wraz dwu nie zwojowal.

Umiera Michal, przez to triumfuje

W niebie nad ziemią, Polska go żałuje $\mathrm{e}^{25}$.

Interesujące są także refleksje Smitha dotyczące elekcji Sobieskiego. Autor najprawdopodobniej nie zna dokładnie mechanizmu elekcji ıiritim. Trudno określić, czy używając słowa „senatus", ma na myśli senat jako taki, czy inną jakąś „radę”, na przykład odpowiednik Sejmu (który jednak określano w lacińskim piśmiennictwie słowem ,conventus”). Uważa poeta, że Sobieski wybrany został ,jednomyślną uchwalą senatu”, co sugerowałoby powszechne poparcie; tymczasem, jak wiemy, mial Sobieski silną opozycję, zwlaszcza na Litwie pod przewodnictwem Michała Paca, którego zwolennicy mawiali już po elekcji, że „cum summmo preindicio Rzeczypospolitej od jej cząstki Sobieski królem nazwany" kawszy wydaje się jednak szacunck naszego poety do samego zjawiska wolnej elekcji:

(...) mox Patres, maxime Ductor,

Comenimut, ac te Regem de more salutant ${ }^{27}$

Et sacra servati toties imsignia Regni

Imponumt. Prisca felices lege Poloni!

Nec Puer imbellis, nec au'ito degener Haeres

Sanguine, nec culto mollis Muliercula lecto

Progrediens vestram possit temerare Coronam,

Et Sceptri Regale decus; Regit ille feroces

Frachator Litawos, bellatoresque Polonos (s. 25-26).

(...) Zaraz się zbiera Senat, o wodzu największy,

Królem ciebie ogłasza, według zwyczaju pozdrawia

Po czym insygnia Królestwa, któremu tyle oddałeś,

Daje. O, szczęśliwi dawnym ich prawem Polacy!

Ani tchórzliwy mlodzieniec, ni degenerat wyrodny

Krwi królewskiej, ni słaba kobieta z toża zacnego

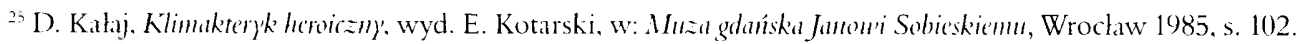
*I. A. Chrapowicki. Diarius ¿́cin, cyt. za: Z. Wójcik, op. cit., s. 218.

2- Tu przyp. Smitha o clekcji Sobicskicgo w 51. roku życia: "Iolummes (reatus Rex Poloniac, Ma)' 23. 1674,

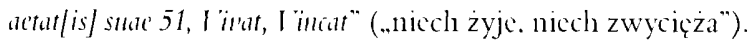


Ród biorąca nie może waszej zbezcześcić korony

Ni królewskiego berła chwały. Król ten swą wladzą

Kiełzna dzikich Litwinów i wojowniczych Polaków.

Najbardziej interesuje jednak Smitha uwydatnienie męstwa Sobieskiego jako bohatera na polu walki. Widzi w nim nowe wcielenie wodzów rzymskich oraz nowożytnych pogromców Turków: Jana Hunyadego i Jerzego Skanderbega (to wlaśnie w Anglii ukaże się po wiktorii wiedeńskiej anonimowy pocmat Sanderbeg reditrinus) ${ }^{28}$. Sobieski jawi się centralną, niezmordowaną i zawsze aktywna postacią w teatrze dzialań wojennych.

Interea mediis castris Sobieschins Heros,

Nil casus, lethiue memor, se fundit in actus

Immumeros, vigili dum prospicit ommia cura,

Et peragit tragicae furialia munia scentue.

Exemplo per mille viros, per tela, perénses

Hostiles, stratosque artus, per funcra, glandes

Fulmineas, mrmasque infansto Marte crnentas

Latmm pandit iter. Sic missi carcere lenti

Unanimes freta caeca fermut. Sic igne trisuloo

Inpiter attonitas iratus concutit Alpes.

Nec mora; lethali iam pectora comminus ictu

Perforat Aemonii Ductoris; Volritur arris

Sanguincis Soliman; Immani vulnere vita

Effugit, et merito clanduntur lumina letho (s. 23).

Zaś bohater Sobieski w samym sercu obozu

Ani na śmierć nie zważa, ani na żadną przygodę,

Czujnie baczy na wszystko, w wir się boju rzucając,

Pełni w ferworze swoja powinność na scenie tragicznej.

Pośród męzów tysięcy, wśród pocisków i wrogich

Mieczy, ciał zabitych i rannych, pośród ognistych

Kul i wrogich zastępów, w Marsa nicłasce okrutnych

Jako przykład toruje drogę. Tak wichry, z więzienia

Wypuszczone, unoszą zgodnie ślepe odmęty.

Tak ognistym piorumem Jowisz Alpy poraża.

Bez zwlekania z bliska ciosem śmierci przeszywa

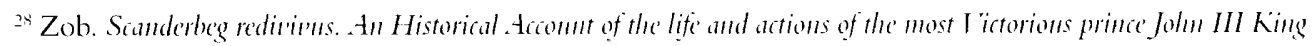
of Poland; containing an Exact and Sucint Series of Affairs from his Cradle to this Present Day..., London 1684 (wyd. II: 1688: por. B. Klimaszewski, op. cit.. s. 136). 
Pierś tesalskiego wodza. Leje Soliman strumienie

Krwi, a z rany potężnej zaraz życie uchodzi,

Śmierć zashuzona niebawen jego powieki zamyka.

Trudno od razu określić, którego to Solimana zabić mial Sobieski w tej bitwie, gdyż czas Sulejmana II jeszcze nie nadszedt, a Mehmed IV, który dowodził wyprawą na Polskę, dożyl spokojnie 1693 roku. Poeta często miesza wprawdzie fakty, nieprecyzyjnie określa daty i okoliczności wojenne. Niemniej warto pamiętać o pewnym epizodzie bitewnym spod Chocimia: wprost na poczet Sobieskiego ruszyły oddziały bośniackie, na czele których stał Soliman pasza; zostały rozbite ${ }^{29}$. Może to wlaśnie zdarzenie stato się inspiracją panegirysty, który mial na pewno jakieś informacje o przebiegu walk. Bardzo plastycznie oddał on w swym wierszu ucieczkę I Iusseina paszy:

\section{(...) En aspice casus}

Incertos belli! Facimus munc sanguine multo

Expiat, et ingulos ultori praelusit e'nsi

Thracius; et faede flectit vestigia retro

Degener, abiectis fugiens inglorins armis

Hussamus Ductor. Quantum mutatus ab illo,

Qui sibi promisit victos dommisse Polonos,

Qui modo stipatus turmis, tot termit Urbes,

Et totos fluvios galcis trictricibus hausit! (s. 24).

\section{(...) Rozważ niepewne}

Wojny koleje! Przelaniem krwi się teraz odpłaca

Zbrodnię. Pod miecz mścicicla oto gardla nadstawia

Turek; teraz niechlubnie swoje zawraca choragwie,

Broń zlożywszy, hańbą okryty, w niegodnej ucieczce

I Iussejn Pasza. O jakże, jakże odmiemny od tego,

Który mial już nadzieję ujarzmić i złamać Polaków,

Który z gromadą oddziałów miasta trwogą napełniał

Oraz hełmem zwycięskim wszystkie rzeki wyczerpal.

Musimy wreszcie powiedzieć, że angiclski autor, który dal nam laudację Sobieskiego jako męża opatrznościowego Europy, rysuje się na podstawie badanego przez nas tekstu jako prawdziwy człowiek baroku, świadomy swych czasów jako epoki wojny, miłości, ce-

\footnotetext{
2"Zob. L. Podhorodecki. Sobiescy herlu Jamima. Warszawa 1984, s. 116. Za pomoc w ustaleniach dziçkujemy mgr. Jackowi Trzeciakowi.
} 
remonialnych widowisk i literatury. Najciekawsze wydają się właśnie scenly batalistyczne, w których szczególnie sugestywnie brzmi potoczysty heksametr:

Omnia sulphurens connolvit noctis amictu

Fumms et aetheres bellantibus abstulit Ignes.

Sed validae micuere manus; sternumtque caduntque,

Vulnera vulneribus redimumt; fundumtque rumutique

Nunc plumbo, unuc ense truces; infractaque bello

Pectora, magnamimique Duces, animaeque capaces

Mortis, et acternae captantes praemia fanae

Egregii cecidere lini (s. 22).

Dym siarczany spowija wszystko pod nocy osloną,

Swiateł nieba walczącym nawet widzieć nie daje.

Lecz migoczą waleczne ręce: biją, padają,

Rany zadają, rany odnoszą, strzelają i sieka,

Raz olowiem groźne, raz mieczem; serca niezłomne

W boju, wodzowie wspaniali o duszach gotowych

Umrzeć, biorąc w nagrodę wiecznej sławy zaplatę,

Padli, wielcy mężowie.

Znakomicie potrafi autor przystosować formuly poezji lacińskiej do sugestywnego opisu takich zjawisk, jak na przyklad wybuch szrapnela:

Machina, perque domos, tonitrus imitata Deormm,

Sacta boat, turresque ac alta cacumina sternit.

Et globus inmmanis ('asto qui plurima ventre

Ferrea tela capit) se tollit in acra motu

Obliquo, occultum servans in funcra pondus,

Flammitomamque trahe'ns candan; delapsus ab anris

Iam cadit, horrendumque sonans, sha viscera rmmpit (s. 33-34).

Sroga, wielka machina, grzmiąca jak piorum niebieski

Ryczy wśród domów i wali wież wysokich wierzchołki

Kula wielce potężna (która we wnętrzu ogromnym

Mieści wiele żelaznych pocisków) łukiem wzlatıje,

Swym tajemnym ładınkiem śmierć zwiastıje dokola

Ciągnąc za sobą ognisty ogon. Już pada na ziemię,

I Iuk potworny wydając, swoje wnętrzności rozrywa. 
Poemacik Snitha zasługuje zapewne na bogatszą analizę, na którą w tym miejscu nie starczy nam miejsca, a na pewne ustalenia wydaje się jeszcze za wcześnie. Jedno warto stwierdzić: panegiryk ten pozostaje w wybitnej harmonii z duchem czasu. Znamienne jest, że ukazał się w roku 1679, czyli wówczas, kiedy Sobieski podjął realne przygotowania do zmiany orientacji profrancuskiej na prohabsburską. Orientacji takicj już od dawna w pewnych kręgach od niego oczekiwano. Jak wiemy z wiersza Stanisława Morsztyna, nieco po koronacji króla, w kwietniu, odbyło się jeszcze w ramach uroczystości koronacyjnych, widowisko baletowe. W jego finale pojawia się znamiemna personifikacja:

A na ostatku za wszystkimi w tropy

Idzie wizerunk calej Europy,

Cow niej jest królestw, powinny z ochotą

Zwycięzcy pogan oddać siç obronic,

A choć już u nas ma koronę zlotą,

Laurowemi zdobią pańskie skronie ${ }^{30 !}$.

Także Smith kończy swój poemat przemową nosobionej Europy i wizją narodów (również brytyjskich) zjednoczonych pod przewodem cesarza i papieża. Wzywa opatrznościowego męża:

Tu, supermum auxilits fretus, Tu suscipe solus

(Namiue potes, solus) Tu Rex fortissime, sacrum

Suscipe Martis opus; per inhospita Regha Tyranni

Duc, age, lictrices tremefactu per Arwa Phalanges;

Fige trinmphatis vexilla minacia muris

Et rape barbaricas Turaram fronte Tiaras (s. 40).

Ty zaś z nieba pomocą ruszaj na morze, podejmij

Sam (bo przecież sam możesz), królı mężny, podejmij

Święte dzieło Marsa. Przez drżące pola poprowadź

Swe zwycięskie falangi w tyrana kraj niegościnny.

Zatknij na murach zdobytych dumnie wzniesione proporce,

Barbarzyńskie korony zerwij ze skroni tureckich.

Glorii Sobieskiego przyszło się jednak wypehnić nie na wschodzie Europy, lecz pod Wiedniem, który mial być kolejnym niewykorzystanym triumfem polskiego wodza. Takie są bowiem, na co i nasz autor często zwraca uwagę, niepewne obroty Fortuny i losów ludzkich. Ale to już zupehnie inma historia.

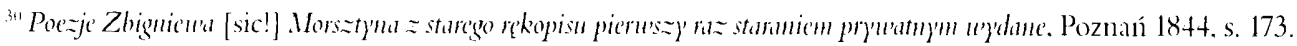

